\title{
TEACHING MODERNITY: THE PKI AS AN EDUCATIONAL INSTITUTION
}

\author{
Ruth McVey
}

When after the coup of October 1, 1965, the masses were permitted to express their wrath by burning down the Indonesian Communist Party headquarters, the army was careful to seize the party's archives first. Indonesian academics were called in to analyze some of these documents, particularly the records of research into village conditions which the party had recently sponsored in Java. One such scholar remarked to me on his great surprise at the level of sophistication of the surveys which rural PKI cadres had supplied to the party. The authors of the reports had clearly been peasants with very little schooling, and their contributions were often penciled on grubby scraps of paper, but they showed genuine analytical ability. How had the Communist party managed to teach peasants to do this? And what did it imply for the future?

The rural sophistication which my colleague noted twenty-five years ago was the fruit of the Partai Komunis Indonesia's educational work. This had been a major focus of the party's activity in the 1951-1965 period, but most accounts of the postrevolutionary PKI have slighted it in favor of other, more directly power-related aspects of the movement. It is worth recalling, however, because it helps to explain communism's appeal in that era and also because it places the PKI more clearly in Indonesia's historical and cultural development.

It was understandable that Indonesian Communists formally recognized education as an important subject. Marxism, as a movement of nineteenth-century European intellectuals who sought to bring the masses to a scientific understanding of their condition, placed great value on both theoretical study and the "making conscious" of the working class. However, which of these two aims achieved priority differed very much from one group of Marxists to another. Some-such as the Dutch socialists in the Netherlands Indies who came to form the revisionist ISDP (Indies Social Democratic Party)-were more interested in the former, hence in accumulating a "scientific" understanding of use to socialist decision makers in Europe. Others, such as those who created the more radical ISDV (Indies Social Democratic Association), were particularly concerned to communicate the Marxist message to the colonized masses, and for this reason they cultivated Indonesian protégés, who in time assumed leadership of the movement and renamed it the PKI. Although the party's initial focus was 
in the labor movement, and this remained the core of its strength, its influence spread most rapidly via the school system sponsored by the Sarekat Islam, in which mass movement the PKI initially participated.

"Wild schools" outside colonial government control, such as the SI school system, flourished in the early decades of the century because Indonesians were coming to realize that giving their children Western-style education was the only practical way to ensure them a better future. Moreover, the country's condition seemed to call for a radically new kind of knowledge, one which grasped the secret of the West's success. The Communists' MarxismLeninism made special claims to being scientific, to explaining imperialism and recommending practical ways to combat it, and so it is not surprising that it had a particular appeal for radically inclined young teachers in the Sarekat Islam system-the more so since the founder of the SI schools was the charismatic Communist Tan Malaka. When the PKI and Sarekat Islam went their separate political ways, the SI schools chose overwhelmingly for the Communists.

But perhaps even more important than this for spreading the notion that communism represented an efficacious teaching-an ilmu, a science which would enable people to overcome their colonial condition-was the way in which Marxist-Leninist categories were absorbed during the last two colonial decades into Indonesian nationalist thought. This, which came about partly through traditions and contacts begun by the ISDV/PKI and partly from contacts established by Indonesians studying in the Netherlands, took place largely because of Marxism's apparent ability to trump imperialist Europe's claim to be the true possessor of the science of modernity. Though communism itself was illegal after the mid-1920s and there was little chance to propagate it through schooling, Marxist categories became part of the general nationalist discourse at the elite level. Some of these ideas trickled down to the common folk; moreover, Marxist attachments were kept alive informally among groups of ordinary people that had identified with the PKI in its earlier heyday. They were passed on among relatives and neighbors and by something very like the traditional guru-murid system for transmitting spiritual knowledge. In this way highly personalistic and speculative visions of communism were conveyed by men who relied on moral presence rather than any real knowledge of Marxist tenets as their source of authority. Though there was some contact between groups and occasionally even overseas, there was little attempt by them to constitute an organized underground. Rather, as with more traditional groups seeking spiritual renewal, they concentrated on maintaining their own particular world of discourse and on "gathering strength" against the day when freedom would dawn.1

The children of this prerevolutionary generation of Indonesian radicals came to power in 1951 over a now legal but very much reduced PKI. ${ }^{2}$ The circumstances under which they

\footnotetext{
${ }^{1}$ One such group was established by the lawyer and labor leader Mohammad Yusuf in the 1930s; D. N. Aidit, the postrevolutionary chairman of the PKI, was one of its young adepts. In the early days of the Japanese occupation Yusuf formed the "Joyoboyo Movement," envisaging, in accordance with an old Javanese prophecy, the speedy acquisition of independence after rule by yellow men. In October 1945 Yusuf re-established the PKI under his own leadership, no one else having declared a legal Communist party in the Republic. PKI-oriented groups then made themselves known to the new party headquarters, writing in or sending emissaries to inform it of their existence and claims to constitute local party units. Yusuf led this higgledy-piggledy but enthusiastic conglomeration until his arrest and the return of exiled and more conventional Communist leaders in early 1946. ${ }^{2}$ Of the top PKI leaders, D. N. Aidit had a father of radical nationalist persuasion but who, in keeping his job as a forestry official, joined no party during the colonial period; after the revolution he briefly represented the PKI in parliament. As a commercial high school student in Batavia, Aidit became involved with Mohammad Yusuf (see footnote 1), who tutored him in Marxism; he was staying in Yusuf's house when the latter was arrested by the Japanese. M. H. Lukman grew up in the concentration camp of Boven Digul, where his father, a radical kyai from
} 
had grown up had taught them that there was no contradiction between communism and Indonesia's national self-realization. Indeed, they believed that it was only by following Marxist-Leninist principles that Indonesia would really free itself from imperialist influence and achieve social justice. That the PKI had not managed to convince the Indonesian people of this during the 1945-1949 war of independence they put down to the perverseness of the leftist leaders of that period, most of whom had spent the war years in Europe or Australia. On returning to Indonesia these leaders had relied on international thinking and could not believe that the Indonesian populace was willing to follow a Communist party acting in its own right. Their failure to present communism as the natural focus of the Indonesian revolution had, so their young successors held, dissipated the Left's strength and led to compromises which permitted a rightist assumption of power and eventually a disastrous clash with the Republic's government.

All this had reduced the PKI to a barely tolerated sect at the end of the independence struggle; but to the mind of the new generation of party leaders it did not mean the end of communism's bid to assume command of the national revolution. They perceived the transfer of sovereignty as merely a stage in the revolutionary process, leaving Indonesia independent in name only-a "semi-colonial" state. At the same time, they believed the victory of the Right within the revolutionary republic had not placed the new state firmly in reactionary hands, requiring that Communists frame their efforts in terms of class struggle. As they saw it, the social boundaries between Indonesians were still sufficiently fluid, and the newly dominant bourgeoisie was sufficiently weak and divided, that a turn from national struggle to class struggle was inappropriate. Instead, their task must be to convey to the mass of Indonesians that Marxism-Leninism had the answer to their postrevolutionary confusion, that communism was for everyone and not just the workers, and that it would make them truly free.

Such a program required the ability to reach the mass of the population easily, hence a large size and legality. Moreover, it was not simply a matter of preaching the good word: ${ }^{3}$ people had to be brought to see in concrete ways how Marxism-Leninism would enable them to gain control over their circumstances, and how, therefore, it was the answer to the nation's predicament. The key to this-communism's essence, so far as this generation of PKI leaders was concerned-was modern organization, and the party's principal task was to teach Indonesians how to think and arrange their action in a modern, organized, that is Marxist-Leninist way. ${ }^{4}$

Tegal, had been sent following the PKI-led anticolonial uprising of 1926. Nyoto grew up in Besuki, where his father, a trader and party worker, had fled following a crackdown on Communist activity in Surakarta in 1923. Aidit, Lukman, Nyoto, interviews October 1964-March 1965.

${ }^{3}$ Although sometimes it resembled this: members were at times recruited in a manner reminiscent of religious revival meetings, particularly when the PKI was opening up new areas. See the description of a meeting in Lubuh Pakem, where 53 "honest folk" (orang2 jang djudjur) filled in applications on the spot and others swore to do so shortly (Harian Rakjat, November 21, 1952). Passing from candidate to full membership in the party was a good deal more difficult, though the elaborate screening and indoctrination process set down in the PKI organizational bulletin Kehidupan Partai in 1958 (see Donald Hindley, The Communist Party of Indonesia 1951-1963 [Berkeley and Los Angeles: University of California Press, 1964], pp. 86-87) was the ideal rather than the reality.

${ }^{4}$ I have discussed the importance of the idea of organization for the PKI in a forthcoming essay on "Nationalism, Revolution, and Organization in Indonesian Communism." These essays form part of a group of four studies on ideology and culture in the postrevolutionary PKI; for those interested in pursuing the argument the others are "The Enchantment of the Revolution: History and Action in an Indonesian Communist Text," in Perceptions of the Past in Southeast Asia, ed. Anthony Reid and David Marr (Singapore: Heinemann Educational Books [Asia], 
People therefore had to be taught to be organized not just in order to do things better but in order to be something qualitatively different from what they had been before. And this difference had to be made visible, so that others could see and learn. Thus political theatrics, which found full expression under Guided Democracy, was from the start an integral part of the Communist effort at consciousness raising. It was not just a matter of providing a show: such things were seen as assurances that modernity and power were at hand, that the means were available to turn disorder and uncertainty into safety and confidence. Thus the vision purveyed by the 1953 Jakarta May Day parade:

The most striking thing was the PKI's contingent, perhaps the best-ordered of all. In relays they carried the symbol of their party, a giant hammer and sickle, a banner on which was written in giant letters Partai Komunis Indonesia. All eyes were on them. They were dressed uniformly, all in white, a section of women and then one of men; almost everyone carried the party flag and a red flag. Their discipline was visible for all to see: Their step was as regular as if they were soldiers who understood what order was. A leader walked by the contingent's side. Its members did not chatter among themselves, unlike the other groups. They were a model, the whole contingent was an example from the beginning to the end, unlike the other groups, whose members dropped out one by one as they grew fatigued. 5

For this reason, such items as "culture and sport" on the agenda of cadre courses were not a relaxation from the business of the day but concerned with team sports and drills, the mass singing of party songs, the creation of drumbands complete with (since they were apprehended as an integral part of this icon of modernity) modestly clad majorettes.

The PKI was not the first Indonesian movement to employ the visible display of order as a sign, as Jim Siegel showed in the first issue of this journal, 6 and those who were drawn to the ordered ranks of Islam at the mosque showed little attraction to the PKI's ordered ranks on parade. Both were cultural statements, assertions of being different and superior, of being aligned with the Truth.

To learn where the Truth lay and how one should arrange one's life to conform with it, the modern person went to school. With this requirement the question immediately arose as to whether instruction was to be in familiar surroundings and with a minimum of formality, or whether it should be in a place kept apart, which embodied the new order to which the pupil was to be acculturated and which aroused awe and obedience. Governments and established faiths have preferred the latter; new beliefs have often opted for the former, both because it emphasized accessibility and because it required fewer resources. The PKI, with its stress on organization, modernity, and hierarchy, had a predilection for the former, but at the same time lack of funds and the desire to reach the mass of the population as quickly as possible argued strongly for doing without the mystique of the formal school. As we shall see, these two considerations were never really reconciled: as time went on, the PKI pushed further in both directions, developing academies and diplomas for its higher cadres and barefoot classes under a tree for the rural poor.

In the first years, however, the issue scarcely arose: the party made do with what it had, which was not much. Education had to begin in the party itself and in the labor unions

1979); and "The Wayang Controversy in Indonesian Communism," in Context, Meaning, and Power in Southeast Asia, ed. Mark Hobart and Robert Taylor (Ithaca: Cornell Southeast Asia Program, 1986).

5Sastradiredja, "1 Mei di Djakarta," Warta Sarbupri 4, 3/4 (May 1953): 63-64.

6James Siegel, "Prayer and Play in Atjeh: a Comment on Two Photographs," Indonesia 1 (April 1966): 1-21. 
which were then its chief source of strength. Most PKI cadres and labor leaders had gained their positions on the basis of revolutionary association with the broad left; they had little notion of organization, and only anti-imperialist and populist sentiments to sustain them ideologically. Consequently, one of the party's first chores was to instruct its own officials in the basic tenets of Marxism-Leninism. In that way they hoped to establish a framework of discourse ensuring that their adepts spoke on the same wave-length and also reinforcing the PKI followers' sensè of participation in a community of the knowing, of being set apart and privileged and therefore being obliged to discipline and sacrifice on the party's behalf.

Needless to say, such instruction was on a very basic level; in the provinces it very often had to begin with lessons in literacy, for many cadres could not read. Indeed, illiterates continued to be welcomed as party members provided they promised to learn to read and write, a policy which adjusted the PKI's ambitions for massive organization to the reality of Indonesia's overwhelming analphabetism but made it difficult to claim for cadres a particular command of modern matters. In 1957 the party launched an anti-illiteracy campaign (Pemberantasan Buta-Huruf, PBH) aimed at cadres as well as the general public. This called for the formation of groups with a leader who acted as teacher and provided political education along with the alphabet. Thus Aidit or aksi might illustrate the letter $\mathrm{A}$, while $\mathrm{T}$ could be introduced profitably via the slogan tanah untuk kaum tani (land to the peasants). ${ }^{7}$ Beyond this rudimentary level, efforts were concentrated first on providing cadres with a basic Marxist vocabulary, in the same spirit as early nationalist journals had published lists of the new words by which their readers were to understand the modern world; and then they linked these ideas to provide, in the simplest possible manner, some of the basic MarxistLeninist understandings of the world. 8

But ideology alone would not tell the people how to organize, and might not convince them that they were learning something of direct use in mastering the problems of the day. Indeed, when in 1952 the Jakarta organization of the PKI-backed labor federation SOBSI began its first cadre course with an emphasis on theory, those attending had been discouraged and dissatisfied. A year later, its successor was designed to be of practical use for activists in local organizations, addressing itself to such subjects as organization, finance, propaganda, administration, social-economic matters, culture, and sport. ${ }^{9}$ Such knowledge as how to keep a budget, run a meeting, set up a publication, and so on was not only directly useful for making the party and its mass organizations more effective; it gave the cadres a sense that they were gaining mastery over modern methods of action. In fact, practical organization building continued to overshadow instruction on ideological matters, both because it was desperately needed by a party which was always expanding to (and sometimes beyond) its capacity for control and because of the PKI leaders' belief that to be organized was to be in a historical state of grace.

In the 1950s much of this effort was carried out in relatively short-term and ad hoc courses in individual labor organizations or the party itself. The ideal was to have the most rudimentary lessons in being a Communist given at the local level, both because it involved less disruption and expense and because it allowed adjustments to local conditions and

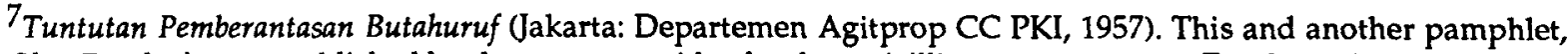
Obor Revolusi, were published by the party as guides for the anti-illiteracy movement. For the welcoming of illiterates into the party see M. H. Lukman, speech quoted in Harian Rakjat, September 21, 1954.

${ }^{8}$ Examples of some of the literature published by the PKI's Department of Agitation and Propaganda for use as elementary texts in party schools include $A B C$ Politik, $A B C$ Revolusi Indonesia, Mengapa Front Nasional, and Bagaimana Masjarakat Berkembang (all issued in 1957 or 1958).

${ }^{9}$ Harian Rakjat, October 16, 1953. The course lasted a month, on a part-time basis, and included 188 cadres.
} 
capabilities. The problem was that there was often no one locally who could provide even elementary training. Furthermore, union and party bosses who had achieved their roles through personal leadership were often uninterested in instructing their followers in alternative ways of doing things. The new PKI heads, on the other hand, were determined to detach their units from such leaders, for they were not only an obstacle to the modernization of the movement but a source of resistance to central control. Consequently, early efforts at training and organization made great play with collective and democratic decision making and railed against "commandism" and insufficient faith in the capacity of the common worker to understand matters of theory. 10

For courses that were held at the regional or central level-the serious ones, in terms of content and career-the selection of those to attend was supposed to take place by collective decision of the leadership of the relevant unit. The candidate should be someone who could be relied on to spread his knowledge on returning to his home area. He must already have been active locally in the workers' cause, must want to study, and must be able to read, write, and speak Indonesian. It would be best if he had already attended a local cadre course, and had some experience in ideological discussions, for neophytes had trouble following the courses and "would become confused hearing such terms as 'workers' struggle." 11 And then, of course, the candidate for a training course had to be proposed to the sponsoring level of the organization, which would invite him; his leave had to be arranged if he was employed and a replacement found if he was an organizational full-timer. Not least, members of the local had to arrange to support his family and provide for his travel.

Some sort of collective accommodation was usually provided for those taking courses at higher levels, both because this meant they attended instruction more regularly and because one of the acknowledged purposes of the courses was to form a network of organizational friendships which crossed local and regional boundaries. The length of the courses differed greatly, but travel was too difficult and the trainees' lack of background too great for short courses to be practical. In a few weeks, a union commentator noted, one could deal with urgent matters of the day; for any serious training one needed to have at least three months. ${ }^{12}$

In spite of all the emphasis on promoting from the ranks, it not infrequently happened that promising worker activists were not given real responsibilities because, in the eyes of local party professionals, it would have involved too much time teaching them the rudiments of literacy and organization; instead, party officials who already had some education took on responsibility for running a number of organizations, even though this meant their attention was stretched very thin. And, despite the emphasis on seeing that cadres sent for training at higher levels returned to their home areas, they very often took the chance to gain a posting in the ever-expanding central apparatus, to the extent that the bleeding of local organizational talent to Jakarta became a chronic problem. Nor were lectures by busy party notables perhaps always the revelation they should have been. Nonetheless, it is remarkable how much was accomplished by way of communicating new modes of thought

\footnotetext{
${ }^{10}$ See for example "Pesan DPP Sarbupri dalam Memperingati 6 Tahun Sarbupri," Warta Sarbupri, 4, 4 (March 1953): 5; M. Chairuddin, "Bekerdja untuk Memperkuat Sarbupri," ibid. 4, 16 (December 1953): 304, 309; Warsosukarto, "Kedudukan dan Tugas Sarekat Buruh," ibid. 6, 8 (August 1955): 144. The plantation workers' union Sarbupri was the early center of the postrevolutionary PKI's labor strength; it was more open and exuberant than most other unions, and discussed organizational problems with considerable frankness in its publications.

${ }^{11}$ Hasan Raid, "Beberapa Soal tentang Pendidikan Kader," ibid. 4, 9 (August 1953): 168; and see generally pp. 167-74.

12Ibid, p. 167.
} 
and action to a large and disparate number of people, and this in spite of the rudimentary state of the party educational apparatus. An attempt was made by the labor federation SOBSI to set up a system of schools at central and regional levels in order to provide continuing cadre training, individual unions being asked to provide basic education and also specialized professional knowledge for their activists. ${ }^{13}$ However, this program fell foul of the worsening economic and political conditions of early Guided Democracy and then, more fatally, of the party's decision to concentrate its attention on the peasantry.

Much of the early educational effort, in unions as well as the party, was carried out through publications. During the 1950s the plantation workers' Sarbupri, which was particularly active in such things, sponsored regional organs in Sundanese, Javanese, and Indonesian, and even some branch organizations had for a time their own organ. ${ }^{14}$ Overwhelmingly, they were concerned with questions of how to organize. Matters which in more established Communist movements (and in the PKI itself after the transition to Guided Democracy) were considered appropriate only for restricted internal discussion were freely aired here, in an enthusiasm for spreading knowledge about the techniques and problems of organization.

Publications were also used to reach ordinary workers, though given the high level of illiteracy this was less by way of direct communication than by oral discussion. Activists among the workers brought leaflets which concerned local conditions to the houses of their friends, and initiated discussions with an eye to spreading militancy and an interest in organization. The fact that management in various enterprises reacted sharply against the spreading of leaflets in the workplace had, it was observed, the beneficial effect of persuading workers that the writings were sufficiently powerful to make the bosses afraid. ${ }^{15}$ In general, however, meetings were considered the way to involve the workers, and activists were urged to hold as many group discussions on locally important issues as possible, paying special attention to the teaching and control of workers whom they selected to act as leaders of the groups. Admittedly, it was not always easy to get ordinary folk to speak their minds; but once they had some practice in airing issues among themselves they would acquire a more critical and outspoken spirit. However, as one article noted, there were union activists who feared this as much as did the bosses, for not a few disliked the idea of a following that could think for itself. ${ }^{16}$

\footnotetext{
${ }^{13}$ Dokumentasi Kongres ke-VI Serikat Buruh Kereta Api (SBKA) Jakarta: Pimpinan Pusat SBKA, 1957), p. 90. The SOBSI schools were to provide courses on the history of the labor movement, [the Communists'] socio-economic program, achieving workers' unity, and how to strengthen SOBSI and its constituent unions. The railway workers' union SBKA decided, in line with the SOBSI program, to provide its cadres with instruction on technical railway matters, administration, employment practices, and so on. Expertise of this sort was to come in handy when, under the conditions of Guided Democracy, SOBSI cadres were able to provide state managers with both the technical knowledge and ability to control the workers that competing organizations such as the armyfavored SOKSI lacked.

${ }^{14}$ The West Java Sarbupri regional leadership published Panggeuing in Sundanese; Central Java brought out Kolowarti in Javanese, and East Java Berdjoang in Indonesian. BODSU (Berita Organisasi Daerah Sumatera Utara), in Indonesian, was the North Sumatran version, and Pembebasan was published in South Sumatra. Branches with their own bulletins included Sukabumi, Banyuwangi, and Palembang. (Warta Sarbupri 6/7, 2 [1956]: 36). These, rather than the central Warta Sarbupri and Berita Organisasi Sarbupri, were circulated among lower organizational levels. They declined with the takeovers of the Dutch-owned estates and the declaration of the State of Emergency.

${ }^{15}$ Warta Sarbupri 5, 7 (July 1954): 126.

${ }^{16}$ Ibid. 5, 12 (December 1954): 238-39.
} 
Within the party itself, educational efforts were concentrated within the local group and endeavored to convey understanding of the PKI's constitution and program. In addition, a number of journals and pamphlets were published and made available through partyoriented bookshops and libraries attached to party branch committees; study groups were organized to discuss publications of major importance, and intra-party conferences and seminars were sponsored on matters of current attention. Party schools (sekolah partai, SP) were sponsored by the center and some regions in order to improve their cadres' political sophistication. Beginning in 1956 with a three-year plan to improve the party's organizational and educational level, the PKI set targets for central and subordinated party committees to achieve in order to ensure that a significant portion of their energies went into these essential infrastructural activities. 17

Nonetheless, as the movement's following expanded illiteracy presented an ever greater obstacle to getting the Communist message across and to transforming vague and unrealistic expectations into disciplined, steady participation. With the party apparatus spreading into areas far from its old centers of strength, the problem of insufficiently lettered (let alone doctrinally informed) cadres became acute. It finally appeared necessary to embark on a major educational program, aimed first at literacy and then at providing political skills. Such a system, it was hoped, would not only serve PKI adherents but bring enlightenment to the common people as a whole. Ordinary folk would thus see the party's usefulness; they would be able to compare its efforts with the failing government school system, and by participating they would be introduced to Communist ways of thought and drawn into an intellectual universe centered on the party.

The first and principal institution set up for this purpose was the People's University (Universitas Rakjat, Unra). ${ }^{18}$ Its inspiration was the volksuniversiteit adult education system which had been highly successful in extending learning among working people in the Netherlands. ${ }^{19}$ During the colonial period, nationalists had taken over the idea as a way of providing both a needed service for their following and a way in which to instill a new spirit among Indonesians. Prominent Batavia PNI leaders formed the Perguruan Rakjat in 1928 for the purpose of providing training to become "a conscious and community-minded individual, dutiful and orderly; we want to lay the basis for physically harmonious development, a Human Being who, with a cheerful willingness to sacrifice, will place himself in service of the Indonesian Fatherland." 20 The Perguruan Rakjat had drawn much of its ideological inspiration and teaching methods from the Taman Siswa, the most prominent "wild school" movement of the colonial era, and the Taman Siswa likewise had considerable

\footnotetext{
${ }^{17}$ A good discussion of the first (1956-1959) and second (1960-1963) party educational plans and other efforts to improve PKI cadre quality can be found in Hindley, The Communist Party, pp. 81-101.

${ }^{18}$ As a system, this was officially inaugurated in late 1958 (see ibid., pp. 94-95), but in some cities fundraising and organizational committees were active a year or more earlier. For an early statement of the Unra's purpose by its chairman, Siswoyo, see Ilmu Pengetahuan untuk Rakjat Tanah Air dan Kemanusiaan (Jakarta: UniversitasRakjat, 1959).

${ }^{19}$ Siswoyo and Porkas Daulae, interview, Jakarta, February 1965.

${ }^{20}$ From the statement of purpose of the Pergoeroean Ra'jat given in the Mededeelingen der Regeering omtrent enkele onderwerpen van algemeen belang (juni 1930) (Weltevreden: Landsdrukkerij, 1930), col. 49. The institute taught such practical courses as bookkeeping and stenography, but the main goal was to train people who would act as teachers in a Nationalist-sponsored independent school system. Economic depression and political repression kept it from really getting off the ground.
} 
influence on PKI educational thinking, a number of the party's cadres having graduated from and taught in that system before the war. ${ }^{21}$

Although relieving party and mass organization units of the burden of providing basic education had been an initial motive for establishing the Unra, the system functioned from the start at a higher level, requiring the completion of primary schooling for acceptance. In part this was because the volksuniversiteit model had been for further, not basic, education; more importantly, the need for improved cadre training continued to be urgent. Party and mass organization activists were readily available, they would take more easily to schooling, and their demands for the improvement of their skills could be met. Consequently, little effort was made to attract participants among the common folk: fees, while modest, were too high for working-class Indonesians to afford (party and mass organization units usually paid for cadres they sponsored at the schools), and most of those who attended were lower civil servants and party or mass organization activists. This orientation was reflected in the overwhelming choice of politics among the five courses offered at the Unra schools, which served first of all to improve the doctrinal knowledge of those who attended them. ${ }^{22}$

The politics course consisted of Marxism, the history of the Indonesian independence movement, Indonesian society and economy, Indonesian history, constitutional law, geography, and world history. The overwhelming importance of Indonesia-oriented subjects is typical of the nationalist inclination of the PKI of this period. Much of the course contents consisted of studying and discussing writings on the subject by Aidit or other current PKI leaders, which further emphasized the insularity of the indoctrination. This overwhelming concern with things Indonesian did not just reflect the PKI leadership's interests but was undoubtedly the orientation of the party's following as well; subjects that were not taught with specific reference to Indonesian conditions were of little interest, as the PKI had discovered in its early intramural cadre training efforts.

In September 1959, a year after the Unra had been formally established, it claimed 2,816 students enrolled in ten schools in Indonesia's major cities. ${ }^{23}$ However, the courses were proving far from satisfactory. For one thing, cadres of all levels attended them, and what would satisfy a provincial labor organizer would not necessary attract a party chieftain in search of higher theoretical knowledge. For another, the courses, which usually met three times a week in the late afternoon, required two years to complete, and few had the stamina to see them through. Busy cadres often had to skip sessions, which meant that classes moved forward slowly. The teachers-of whom there were never more than six or seven at even the largest schools-were usually party officials, who took on Unra lecturing as another of their many organizational chores. The schools had almost nothing by way of buildings or equipment, and reading material was limited largely to stenciled lecture outlines and various party publications used as texts. ${ }^{24}$ In short, there were many reasons for a

\footnotetext{
${ }^{21}$ However, Siswoyo, who headed the Universitas Rakjat from the start, had attended not the Javanese nationalist Taman Siswa but the reformist Muslim Muhammadiyah school system as a youth. See Parlaungan, Hasil Rakjat Memilih Tokoh2 Parlemen (Jakarta: c.v. Gita: 1956), p. 292.

22Hindley, The Communist Party, pp. 94-95. The five courses were political science, English, journalism, art, and Indonesian language and literature. Of these, only the first two were available at more than two of the ten Unra schools.

23Ibid., p. 94. The schools were located in Jakarta, Kebayoran Baru, Bandung, Surakarta, Semarang, Surabaya, Malang, Palembang, and Medan.

${ }^{24}$ The schools met in buildings belonging to the PKI or its mass organizations, or in some cases were rented. Some financial aid and equipment was obtained from embassies of socialist countries (see ibid., p. 94), and small
} 
participant to become discouraged, and the drop-out rate soon reached alarming proportions. By 1961 it was clear the system was in deep trouble, and that if it was to continue it would have to be radically revised. The following year was spent discussing the changes that were needed, and in July 1963 a new-model Unra (Unra Gaja Baru) was proclaimed, with party chairman Aidit himself as its head. ${ }^{25}$

The new version of Unra was born as Indonesia entered the final stage of Guided Democracy, and in its innovations it reflected the concerns of those years. In the first place, it now addressed itself squarely to the task of educating the common folk, particularly in the rural areas. The PKI, having seen its ability to wield labor union strength severely curtailed by the army take-overs of Dutch enterprises and the ensuing restrictions on strike actions, had finally resolved to emphasize the peasantry in fact as well as rhetoric. This meant a particular effort to make rural people politically conscious and not just generally sympathetic to what they imagined the Communist party stood for. One consequence was a new emphasis on confronting class divisions within the peasantry, which was to lead to the ill-starred land reform campaign of 1964; another was a major drive to extend a party-linked mass education program to the rural folk. In this fashion,

... illiterate people will learn to read. Those who feel themselves lowly will be raised from the mud of humility to the conviction that labor is noble and that the working people, including the peasantry, are the creators of this world, that what the landlord does to the peasant is not beneficial but exploitative and evil, that the landlord is not an exalted, saintly person but a dirty and cruel fellow, that his authority is not eternal but can be shaken and in the end overthrown by a broad and courageous united peasant front. ...26

The most basic work-bringing literacy and the Communists' general message to the villages-was assigned to the Indonesian Peasant Front (BTI) mass organization, which took over the main task of pursuing the anti-illiteracy effort. Its campaigns were to run during the harvest season, when spirits and cooperative efforts ran high. The idea was to spread literacy as rapidly as possible-within two months pupils should be able to read and writeby employing the principles of "many teachers, a limited number of pupils, modest space and equipment, and concentrated instruction." To make the campaign a success, courses were organized for people who would act as PBH teachers, and "model areas" of literacy were to be developed which would serve as a beacon to the rest. In addition, peasant front locals were supposed to organize creches for village children during the planting and harvest seasons, and to sponsor primary schools (sekolah dasar sederhana, SDS) which would cater to children who had been forced by poverty to leave government school. ${ }^{27}$

These elementary institutions were to feed into a vastly expanded Unra system, whose central purpose continued to be to train cadres who were "intelligent, brave, and cultured";

grants were also obtained from the Indonesian Ministry of Education for such things as benches and writingtables (Siswoyo and Porkas, interview, February 1965).

25 Siswoyo and Porkas, interview, February 1965.

${ }^{26}$ Harian Rakjat, February 22, 1964, from a lecture by the BTI leader Asmu to an Unra cadre and teachers' course.

27 Pupils could attend these SDS schools without needing to wear a shirt. Their hours of instruction were to be arranged in accordance with the students' work schedules, as a major reason for children dropping out of government school was the need to help their parents. They taught the basics: reading, writing, arithmetic, and only later history, geography, and natural science. Cultural uplift was to be given attention, in particular by training the students to form choirs for singing revolutionary songs. Ibid. 
but its organization was now to be extended far beyond the major cities. ${ }^{28}$ It was divided into three levels: the original schools, redubbed Mimbar Pengetahuan Rakjat (Mipera), became the highest division of the new system, offering education at the level of senior high school (SLA). At junior high (SMP) level there was now established the Balai Pengetahuan Rakjat (Bapera), and at the primary level the Panti Pengetahuan Rakjat (Panpera). The last of these Aidit declared to be the core of the Unra effort, designed to create a self-conscious and well-organized rural population, and he devoted a good deal of energy over the ensuing two years to chivvying party units which neglected it. ${ }^{29}$

The new Unra paralleled the state school system, and indeed most of the subjects taught were the same: the principal difference was that the higher Unra schools included ideological subjects, though they placed less emphasis on them than in the past, for now the stress was on training people to be expert as well as red. ${ }^{30}$ Therefore the exact sciences and general knowledge were to be stressed, and still more importantly a modern civilization was to be imbued. The Indonesian citizen of the future had to be a new man culturally, Chairman Aidit pronounced, for only through a profound civilization transformation would he be able to overcome the country's problems. He must become able to see the world through the lens of dialectical and historical materialism (MDH), which would align his vision with the truth. Thus the Unra's task was to make Marxism, the philosophical expression of this approach, the possession of the Indonesian masses and of the Indonesian nation. ${ }^{31}$ In the shorter term, an Unra education would acculturate students to the world proposed by the PKI, making

28 Harian Rakjat, October 17, 1963.

${ }^{29}$ See for example ibid., February 12, 1965, reporting a lecture to Unra cadres by Aidit on February 5, 1964. The Panpera did not overlap with the Sekolah Dasar Sederhana, as-like the other Unra schools-it was intended for adult education. Because the students were adult and often highly motivated party cadres it was initially assumed the Unra schools would be able to accomplish in two years of part-time education (ideally three times a week, in four hours of forty-minute lessons, but in fact whatever arrangement was convenient to teacher and pupils) what state primary schools conveyed in six years of full-time work (ibid., October 17, 1963). It soon appeared, however, that this was unrealistic, and instead it was determined that a student would have to have the equivalent of third-grade knowledge before entering the Panpera. Consequently, illiterates had first to attend $\mathrm{BPH}$ or other preparatory courses for about ten months in order to attain the rudiments of literacy. Ibid., April 30, 1965, report of the third Unra national conference.

${ }^{30}$ The primary schools (Panpera) were to provide courses in 1) Manipol (i.e., the PKI's understanding of official Guided Democracy ideology), 2) Indonesian language and literacy, 3) arithmetic, 4) geography, 5) life sciences, 6) history, 7) nature study, 8) singing, 9) drawing, and 10) introduction to philosophy (i.e., the principles of dialectical and historical materialism). The Bapera was to teach 1) Manipol and civics, 2) Indonesian language, 3) English language, 4) Indonesian and world history, 5) geography, 6) life sciences and health, 7) algebra and geometry, 8) natural sciences, 9) bookkeeping and commercial accounting, 10) philosophy. The Unra proper was to cover 1) Manipol, 2) economics, 3) government and civics, 4) Indonesian history, 5) world history, 6) geography, 7) Indonesian language and literature, 8) English, 9) cultural anthropology, 10) algebra, 11) physics and chemistry, 12) bookkeeping and commercial accounting, and 13) philosophy. It may be imagined that this represented the ideal rather than actual practice. Harian Rakjat, October 17, 1963. For a detailed outline of the Unra syllabus see UNRA Gaja Baru 2 (Jakarta: Jajasan Universitas-Rakjat, 1964). This was part of an intended series for the guidance of Unra instructors; only vol. 2 was published.

${ }^{31}$ Harian Rakjat, April 27, 1965, lecture by Aidit to the third national Unra conference; Harian Rakjat Minggu, article by drs. Bismo Wignyoamijoyo, discussing a lecture by Aidit to Unra cadres on April 5, 1965. In illustration of the way in which Marxism-Leninism was taken as the prism through which the world must be seen, leaders of Aliarcham Academy (see below) contrasted their approach to research with that of Western social scientists such as myself. You, they said, gather data and draw conclusions on the basis of what you observe from them; we gather data and then evaluate their significance in the light of Marxism-Leninism, since we know that this will provide the correct answers (discussion after a lecture at Aliarcham Academy, March 1965). Similarly, the PKI rejected "science for science's sake" as firmly as it did art for art's sake in its cultural battles: science must serve 
them both more loyal and more effective participants in the movement. Technical knowledge such as mechanics and radio repair could increase an individual's fortunes, but it was social sciences and general knowledge taught from a progressive viewpoint that would create revolutionary cadres who made few mistakes in their work among the people. ${ }^{32}$

The Unra schools were not recognized by the state (indeed, since they consisted of twoyear, part-time courses it would have been difficult for them to achieve comparable levels), but neither were they opposed by it, 33 for by now the public school system was in a state of advanced decay. Like other bureaucratic institutions under Guided Democracy, they had fallen victim to economic decline and political wrangling. Teachers' pay, pitiful enough with inflation, was often not received for months; buildings crumbled and supplies were nonexistent. Many rural primary schools ceased to function at all, as their teachers took on other work to make ends meet. In the cities, parents had to pay increasingly stiff placement money to enable their children to enter the few adequate state schools.

The New-Style Unra was designed to respond to the resulting frustration, offering a badly needed service and at the same time demonstrating that communism could function where sclerotic state bureaucracy failed. This was part of a much larger PKI campaign to demonstrate that the party knew how to solve Indonesia's problems and was therefore a fit source of government; and since this was an increasingly important political plank for the PKI, a good deal of party attention and resources were devoted to making the new educational system a success.

On its reformation in 1963, the Unra adopted a national plan calling for the system to acquire within four years 6,809 primary schools, 1,263 middle schools (usually located in kabupaten towns), and 22 senior high schools in the major cities. This meant a tremendous effort to get competent people to run the schools and to find the necessary funds and material. ${ }^{34}$ The first proved the more difficult task, for in the towns the schools could generally meet in party or mass organization rooms, while in the villages they were often able to use the local school after hours; and a virtue was made out of necessity by declaring that only the simplest equipment was necessary. Do not fall victim to perfectionism, Aidit abjured; if no school building could be had use an ordinary house, and if there was no shelter at all teach under a tree. ${ }^{35}$ Nonetheless, textbooks (or at least some sort of mimeographed course outline, which was all that was usually achieved) could not be done without completely, particularly at the higher levels of the system, and so in 1965 a campaign was launched to raise money for writing and distributing materials for the Unra schools. Under the auspices of the central Unra foundation special bodies were to be set up consisting of Unra cadres, representatives of revolutionary mass organizations, and "progressive entrepreneurs" as an ongoing source of fundraising. ${ }^{36}$ Needless to say, it was the progressive entrepreneursChinese businessmen-who were expected to provide the bulk of the funds.

the People and the Revolution (D. N. Aidit, Pemetjahan Masalah Ekonomi dan Ilmu Ekonomi Indonesia Dewasa ini (Jakarta: Pembaruan, 1964), pp. 25-29.

${ }^{32}$ Harian Rakjat, February 12, 1964, speech by Aidit to a Unra training course.

33 According to Siswoyo and Porkas (interview February 1965), a few very conservative lurah resisted the founding of Panpera in their villages, but that was a very minor problem.

${ }^{34}$ Harian Rakjat, October 27, 1963.

35 Ibid., April 27, 1965, reporting Aidit's lecture to the third Unra national conference.

36Ibid., June 20, 1965, article by Bismo Wignyoamijoyo. 
Pupils were plentiful, equipment could if necessary be foregone, but teachers were essential, and this was the main problem in the expansion of the Unra schools. ${ }^{37}$ One major aid was the rising level of leftist sympathy among schoolteachers, whose discontent at their poverty and marginalization under Guided Democracy was expressed in the defection of a good part from the conservative PGRI teachers' union to form the "unaffiliated" PGRI/NV. ${ }^{38}$ At the village level, most of the Unra system teachers were in fact state school teachers who took on classes in the Unra "wild schools" in their spare time. ${ }^{39}$ Schools at the village level rarely had more than one teacher, and in towns even senior-level schools seldom had more than six, drawn from teachers, local intellectuals, and educated cadres of the movement. Village teachers in the Unra system were given payment in kind by their pupils' families (a system often used to support state teachers as well, given the inadequacy and frequent absence of their salaries); those in urban areas, who usually taught for ideological and party career reasons, received only transport money. ${ }^{40}$

There were no criteria for becoming a teacher in the Unra system other than some education and the right attitude. Courses in philosophy (that is, Marxism-Leninism) were only taught by party members, though given the rudimentary doctrinal knowledge of many within the PKI this did not in itself guarantee the content. By and large, they still relied on discussions of Aidit's major writings and of pamphlets prepared by the party to explain the basic applications of dialectical and historical materialism. In general, Unra teachers taught what they could; teaching staff was too precious and textbooks too few for much energy to be devoted to achieving uniformity of content. A five-day crash course (kursus kilat) was developed to give Unra teachers some sort of grounding in the methods, but this was still embryonic in 1965.41

The lack of central control implied by the teachers' freedom was a general feature of the New Model Unra. When it was decided to embark on a campaign of precipitate expansion it was recognized that the tight national-level supervision that had marked the earlier state would have to be dropped in favor of encouraging local initiatives. ${ }^{42} \mathrm{~A}$ leading body, the "Jajasan Unra," was established at national and regional levels; its main purpose was to encourage leftist organizations and individuals within its territory to take the initiative to start schools, and, although in theory it could inspect them, there was in practice no supervision from above or from local party or mass organization units. ${ }^{43}$ Indeed, often enough Panpera schools were established quite independently, on the initiative of a local teacher or group, which notified the Unra of the school's existence. The party made a virtue of this: the

37 Ibid., April 30, 1965, article by Siswoyo.

${ }^{38}$ Ibid., June 8, July 27, 1964. Thus the coordinator of middle and senior high schools in Garut announced that the kabupaten was suffering a shortage of teachers because wages and rice distributions had become so unreliable that many resigned because they could no longer take it economically. Some took other jobs, while many rural primary school teachers simply became full-time farmers without ever formally resigning their teaching appointments. Pikiran Rakjat, December 18, 1963. For a general discussion on the decline of state education under Guided Democracy, see R. Murray Thomas, "The Effects of Indonesian Population Growth on Educational Development, 1940-1968," Asian Survey 9, 7 (July 1969): 498-504.

${ }^{39}$ Siswoyo and Porkas, interview February 1965.

${ }^{40}$ Siswoyo and Porkas, interview February 1965 . However, pupils in the Unra high schools were expected to pay; Rp. 25 registration fees, Rp. 60 placement fee, and a monthly Rp. 75 in course fees was typical (Kedaulatan Rakjat, September 30, 1963).

${ }^{41}$ Siswoyo and Porkas, interview February 1965.

${ }^{42}$ Harian Rakjat, October 17, 1963.

${ }^{43}$ Siswoyo and Porkas, interview February 1965. 
new slogans were autonomy and local initiative, schools to be shaped according to local abilities and needs. Florid expansion, in this and other PKI activities in the final period of Guided Democracy, meant a greater reliance on communism's aspect as a movement rather than as organization, and greater pressure for recognition by regional and local components. The party leadership was willing to concede this challenge to democratic centralism for the sake of achieving growth, for at this stage the quantity of its support counted more than ever over quality.

By April 1965 the Unra counted 1,531 Panpera, 463 Bapera, and 88 Mipera schools. ${ }^{44}$ It will be observed that, although the number of (village) primary schools was well under the halfway mark for the system's four-year expansion plan, the Mipera schools, located in the great cities, had achieved their goal several times over. A principal reason for this was that the major cities were where funds, potential staff, and high demand were located. The senior Unra schools were still mainly attended by party and mass organization cadres in search of higher qualifications, and this was still the most urgent need for the schools in the eyes of the party apparatus, in spite of Aidit's urgings to concentrate on the peasantry. Moreover, the system's rapid expansion led in many cases to equally rapid collapse, particularly at the Panpera and Bapera levels, where the schools depended on the efforts of a very few people. Too often PKI supporters engaged in "sleepwalking," or formalism, making great play with establishing schools because the PKI leadership had urged it-looking for money, locations, teachers, registering pupils, yet never really making clear to the local community just what the purpose of the school was and why it deserved their continuing support. Once the initial burst of organizing energy had passed and students were faced with the fact that the new institution would not wreak miracles overnight, support for it dwindled. 45 The result was the "mouse tail phenomenon" which had also plagued the Unra in its earlier incarnation, the schools gradually trailing off into nothing. ${ }^{46}$ But in spite of these weaknesses the Unra schools had an impact, for they responded to a popular demand for education and, if the teacher was at all ideologically informed, presented ordinary people with a way of looking at the world that seemed to make sense of their situation. Such efforts were to give rise to the village expertise at political-economic analysis which we noted at the beginning of this article.

If party and mass organization resources were stretched by the Unra expansion campaign, they were not allowed to concentrate on this educational project alone. Instead, it was decided that the best way of consolidating the advances made by the Unra was by establishing still more schools, specializing in training peasant and worker organizational cadres. Thus the BTI's four-year plan adopted in 1963 included a major section on education, calling for the establishment of a central peasant cooperative school catering for some 400 trainees composed of provincial-level BTI cadres. Under that, at the provincial level, there would be regional schools training kabupaten-level cadres, and so on down to the kecamatan level, where crash courses would be organized to educate local branch (ranting) and group (kelompok) heads. The goal was to make all cadres literate, to ensure that each ranting had a body capable of running BPH anti-illiteracy groups, and to establish a model SDS primary

\footnotetext{
${ }^{44}$ Harian Rakjat, April 30, 1965, article by Siswoyo. Of Indonesia's twenty-seven provinces, twenty-one had Unra foundations and six-Banten, Nusa Tenggara Barat, Irian Barat, Sulawesi Selatan, Sulawesi Tenggara, and Riau - were still in a "preparatory stage" (Siswoyo and Porkas, interview February 1965).

${ }^{45}$ Harian Rakjat, July 3, 1965, report by Sudisman to the fourth Central Committee session.

${ }^{46}$ See the articles by Porkas Daulae in Harian Rakjat Minggu, February 14 and March 21, 1965.
} 
school in each kabupaten which would serve as a local example of appropriate teaching methods. 47

An Institut Pertanian dan Gerakan Tani "Egom" was duly established in November 1963 at Cisarua, Bogor, to take general charge of agrarian research and educational institutions; it opened a central cadre school, the Sekolah Tani Egom, in April 1965. Aidit's inaugural speech on that occasion is of interest because it reflected the PKI's growing emphasis on cadres who could contribute to the image of the PKI as national problem-solver. The school, he stressed, should raise not only the revolutionary spirit of the peasants but also agricultural production. Its cadres should be able to give practical pointers concerning rice growing, secondary crops, animal husbandry, fishing, and so on; and they must learn from local peasant practice as well as bring scientific advice from outside. 48

Since the traditional arts were one way of reaching the illiterate masses, and since the PKI leadership saw the modernization of culture as essential to its project of creating a new Indonesian man, attention was also devoted to developing the educational potential of the arts. A general program for this was formulated at a Conference on Revolutionary Art and Literature (KSSR) sponsored by the party in 1964. Special schools and courses should be set up, Aidit urged, to focus the resolve of leftist artists and writers for ideological selfimprovement. There they could make an in-depth study of the PKI's program and policy, improve their knowledge of Marxism-Leninism, master Communist ethics and esthetics, study cultural anthropology, and learn about the history of the Indonesian people's struggle-all things that would help them create works which possessed national identity and spoke to the masses. There should, furthermore, be schools which would improve the technical level of artists-they, too, should be expert as well as red. Reog and ludruk schools could improve the esthetic as well as ideological level of traditional performances, and workshops for writers, painters, and musicians should improve the quality of their craft. All this was part of a New Culture Movement (Gerakan Kebudajaan Baru) which was to create a modern Indonesian man. 49

If the PKI leaders' minds were on educating the peasant masses, their hearts in the final years of Guided Democracy appeared to be at the other end of the social spectrum, with improving their claims among the intellectual elite. Partly this was a product of the current emphasis on communism's ability to rescue Indonesia from its economic quagmire through

\footnotetext{
${ }^{47}$ In addition, libraries and reading groups were to be established at the several organizational levels in order to ensure that cadres kept up both their literacy and their political knowledge. Harian Rakjat, February 22, 1964, lecture by the BTI leader Asmu to an Unra cadre course.

${ }^{48}$ Ibid., April 6, 1965. An attempt to improve the training of labor union cadres was also made in this period, though it received less attention than the efforts among the peasantry. The 1964 SOBSI congress vowed to raise the cultural level of its members and to improve their grasp of Marxism; accordingly if founded the Institut Pendidikan Buruh "Harjono," which essentially revived the Sekolah Sentral SOBSI which had existed fitfully since the late 1950s. As of March 1965 the Harjono Institute occupied one room in the SOBSI's general headquarters but lived in hopes of achieving a building of its own. Most of those who attended had jobs as government officials (pegawai); the courses ran for two months because that was the usual length of leave that officials could attain (the Egom courses for BTI cadres lasted four months). The courses stressed the history of the Indonesian labor movement, history of the international labor movement, and Marxism. Any technical upgrading was left to training courses run by the individual unions. Though the Institute was supposed to take charge of developing a nation-wide cadre education system akin to that launched by the BTI, it was clear that little was likely to come of this in the near future. Interview, Harjono Institute teachers, March 1965.

${ }^{49}$ Harian Rakjat Minggu, February 7, 1965, reporting comments by Aidit to the Conference on Revolutionary Art and Literature on September 1, 1964; and see Harian Rakjat, June 22, 1965, reporting the resolutions of the fourth Central Committee session.
} 
organization and expertise rather than painful social conflict. It also arose from the fact that the party needed to have persons capable of representing it effectively in the Guided Democracy institutions to which it was increasingly admitted. It had always been a matter of annoyance to the PKI leaders of the Aidit generation that their movement had attracted very few of the Indonesian intellectual elite. That they were stand-offish was not surprising, for the very restricted character of colonial education limited higher learning to the upper classes. Moreover, in the independence period a university education guaranteed one a job as a government employee, and there was no such thing as an intelligentsia alienated from and independent of the bureaucracy. The bureaucracy as a whole was determinedly antiCommunist in spite of political pressures on it, and until the end it was a distinct disadvantage for a government official to be known as a PKI member.

University teachers, who were classed as government officials, were generally very conservative, and the PKI's efforts to obtain a greater progressive element in academe generally ran to attacking their "Dutch-mindedness" and lack of support for Sukarnoism, which hardly endeared communism to them. The Indonesian Scholar's Association (HSI) promoted by the PKI tended to attract people of marginal status in Indonesia's academic world-and membership itself was enough to marginalize an academic in the eyes of his colleagues. Although the party made every effort to get people of advanced education and good social standing to take posts in PKI-sponsored institutions, the number attracted remained disappointingly low, with the result that PKI leaders and the few non-party sympathetic intellectuals occupied multiple roles in the leadership of party-sponsored institutions. ${ }^{50}$

University students, from elite families and with their eyes on bureaucratic careers, were also not attracted to the PKI. Moreover, the idealists among them were alienated by the corruption and hypocrisies of Guided Democracy, and they considered the PKI particularly culpable for supporting that system, so that (as the postcoup student demonstrations would show) class attitudes and anti-Establishment ideals combined among them to produce a virulent anti-communism. This was strongest at the elite University of Indonesia, attenuating at schools down the social scale and out in the provinces. The PKI-oriented student association CGMI accordingly tended to draw its greater support from the peripheral institutions. ${ }^{51}$ Only in the final year of Guided Democracy did the CGMI make much headway in the competition for university student followers, and this was largely because of the proliferation of non-state universities whose members were socially insecure. ${ }^{52}$ Understandable

\footnotetext{
${ }^{50} \mathrm{~A}$ good example of the way in which young leftist intellectuals were recruited to serve in the leadership of a number of mass organizations can be found in Ibu Marni, "I am a Leaf in a Storm," trans. Anton Lucas, Indonesia 47 (April 1989): 49-60. While she was probably not as passive a participant as her memoir portrays, the process of drawing a promising young member of the elite into party work, with only a minimal attention to discipline or ideological qualification, seems quite accurate. She was given on-the-job training, as it were, being appointed to head various aspects of mass organizational work at increasingly high levels, with the idea of enabling her eventually to take a leading public position on the PKI's behalf.

51 For the development of the CGMI see Hindley, The Communist Party, pp. 196-98. Most students with leftist inclinations tended to join the Nationalists' GMNI, which offered more useful connections for getting political or bureaucratic positions later. Students disaffected with the regime tended to support the HMI, which was connected to the banned Masyumi party, whether or not they were religiously oriented.

${ }^{52}$ The CGMI claimed to have expanded its membership from 30,000 to 40,000 during 1964 (Harian Rakjat, January 30,1965 ). Of these, only 3,000 were in Jakarta (ibid., February 22, 1965). There were 5,754 members in the North Sumatra and Aceh region (ibid., January 9, 1965). A good portion of the Jakarta membership came from the Baperki-sponsored Res Publica University. In Solo over half the student body of the recently established Universitas Kotapraja Surakarta (UPKS), belonged to the CGMI (Mahkamah Militer Luar Biasa, Berkas no: PTS021/MMLB - IV/UR/1967 di Surakarta. Perkara Utomo Ramelan Ex Walikota/K.D.H. Tingkat II Kotamadya Surakarta. Dalam Peristiwa Gerakan 30 September [typescript, at Cornell libraryl, 2, p. 366).
} 
as the intellectual elite's reluctance may have been, it was a distinct embarrassment to the PKI's claims for Marxism-Leninism's intellectual superiority. The party leaders felt the snub keenly, for they were largely autodidacts in theoretical matters and retained a rather exaggerated respect for the virtue expressed in a degree. ${ }^{53}$

However, if Indonesia's established intellectuals would not be attracted to communism, the PKI leaders resolved to create thinkers of their own, people who would moreover employ their knowledge directly to solve the practical problems facing the country. In 1959 the PKI's sixth congress had adopted a resolution on "Science for the People and the Revolution," which marked the beginning of a major effort to establish the party as Indonesia's leading intellectual force. ${ }^{54}$ Not much more was done, the PKI's attention being absorbed in the next few years by the difficult task of adjusting to Guided Democracy. However, in December 1961 the third Central Committee plenum pressed the issue further, launching a campaign to spread theoretical knowledge-Marxist political economy (EPM), dialectical and historical materialism (MDH), and [Aidit's work on] Indonesian society and revolution (SRI)-among educated Communist cadres and sympathizers, and to apply these to aspects of Indonesian life.

To do this they began to found "scientific academies" which were to function both as research institutions/think tanks and as a tertiary level for Unra education. Thus a person might go from analphabetism to the equivalent of a university degree entirely within a Communist educational system. ${ }^{55}$ Most of these academies were begun in 1962-1964, and most of these were still small and tentatively organized in 1965.56 Like the Unra schools, they ran on a part-time basis and were intended for people who held other jobs (nonetheless, it was hoped that greater maturity and dedication would enable their students to achieve the equivalent of a university degree in three years). As with the Unra, they shared the purposes of providing general education and improving the capabilities of party

\footnotetext{
${ }^{53} \mathrm{~A}$ good example of this was the tremendous fuss made by the PKI over Aidit's admission as the first foreign member of the Academica Sinica in 1963. The Chinese, who clearly hit on the gift that would please him most, granted the accolade on the grounds of Aidit's creative innovations in Marxist theory. (Needless to say, after the coup they announced that they had always warned him that his strategy was all wrong and that Maoist larmed peasant] struggle was the only road to power.)

54 "Ilmu untuk Rakjat dan Revolusi," Bintang Merah (Nomor Spesial Kongres Nasional ke-VI PKI) 1 (Jakarta: Pembaruan, 1960): 329-30; and also pp. 100-103 of D. N. Aidit, "Untuk Demokrasi dan Kabinet Gotongrojong," in the same volume; and see Jusuf Adjitorop, "Kembangkan Terus Pekerdjaan Partai dikalangan Inteligensia," Madju Terus, 1 (Jakarta: Pembaruan, 1963), pp. 169-70.

55 The principal institutions were the Akademi Ilmu Sosial Aliarcham, Akademi Ilmu Politik Bachtaruddin, Akademi Ilmu Ekonomi Dr. Ratulangi, Akademi llmu Sedjarah Roggowarsito, Akademi Ilmu Musik W. R. Supratman, Akademi Ilmu Sastra Multatuli, Akademi Ilmu Teknik Ir. Anwari, and Akademi Ilmu Jurnalistik Dr. Rivai. Harian Rakjat, February 24, 1964. The Ir. Anwari engineering academy offered courses in architecture, civil engineering, and electrical engineering (ibid., October 1, 1964). Further academies for dance and art were planned, together with a Universitas Kesenian Rakjat (Banda Harahap, interview March 1965); the arts were by no means an esoteric subject for a party which placed considerable emphasis on the transformation of traditional culture. In addition, the literary academy functioned as a language school, offering courses in English, Chinese, and Russian (Harian Rakjat, December 16, 1963). Some academies were extended on a regional basis: thus the Akademi Ilmu Politik Ngurah Rai was founded as a Balinese offspring of the Bachtaruddin Academy (ibid., September 28, 1964). In addition, the PKI began to promote teacher-training institutions, of which the most notable was the IKIP Dr. Tjipto Mangunkusumo in Yogyakarta. It offered courses in pedagogy, social science (with specialization in economics), natural science, and the liberal arts (with special emphasis on history), and it offered upgrading courses for teachers. Harian Rakjat Minggu, August 9, 1964.

56 Bachtaruddin academy, one of the largest, accepted 88 students in its first year (1962/63) Harian Rakjat, October 3, 1962). The Ronggowarsito history academy had 11 students in 1962/63, of whom 10 passed the yearend examination, and it accepted 22 students for 1963/64 (ibid., December 19, 1963).
} 
cadres, and they were also placed in charge of party projects for research or policy development in relevant fields. Their entrance requirements were quite stiff by the standards of the day, though concessions were made for keen party cadres: the PKI was determined that its academies would not cut a bad figure in comparison with non-Communist institutions. ${ }^{57}$

The first and by far the most important of these institutions was the Aliarcham academy (AISA), which had been set up in 1959 as the high party school, the PKI's senior cadre training center. It was, as its sometime head B. O. Hutapea noted, the first time such a school had been established by a non-ruling Communist party. 58 After feeling its way with a series of short courses much on the order of the old cadre training exercises, the school began to offer a full-time, three year course concentrating on Aidit's work Sosialism di Indonesia, which was written for use as a text in the higher party educational system. From this it branched into the general study of Marxism-Leninism and the problems of the Indonesian Revolution. 59

Aliarcham academy could only accommodate some forty full-time students initially, and later double that number, so that considerable selection had to be made and a high level of application could be expected. At first, 80 percent of the students were from Java, but, since the PKI leaders were determined to increase the party's Outer Island presence, a policy of preference for non-Javanese was instituted, reducing the central island's portion to about 60 percent. ${ }^{60}$ Full-time students were expected to spend six months at the academy and then six months doing practical work with party schools or mass organizations in the provinces; they also were assigned to do group field research into such questions as village class relationships and workers' living conditions. In addition, a four-year extension course was developed for cadres who could not take leave from their organizational work, and seminars and discussion groups were held for high party leaders who wanted to occupy them-

${ }^{57}$ Thus the Bachtaruddin political science academy required completion of SLA (or the equivalent in experience plus an oral examination, this principally for party cadres), plus an entrance examination in the history of the Indonesian independence movement and knowledge of the Pancasila and Manipol/USDEK, general knowledge, Indonesian, and English. Registration fees were Rp. 300, and tuition was Rp. 3,000 a year (Harian Rakjat, July 17, 1964). The Dr. Ratulangi economics institute had the same fees and roughly the same requirements; the entrance examination consisted of the history of the Indonesian independence struggle, knowledge of the Haluan Negara and Dekon Guided Democracy principles, and demonstration of ability to write essays in Indonesian (ibid., September 5,1964$)$.

${ }^{58}$ B. O. Hutapea, "Proletariat Indonesia Selahirkan Intelekuil2nja Sendiri," ibid., April 20 and 21, 1964. Officially the Aliarcham academy was open to the public, in order to qualify for a government subsidy; in practice entrance examination requirements for relevant experience and knowledge of Marxism-Leninism eliminated all but party cadres (Sucipto and Sugiono, interview, Jakarta, March 1965).

${ }^{59}$ There were five departments at the academy: 1) Philosophy, offering courses in the history of philosophy, dialectical materialism, historical materialism, Oriental philosophy, and the development of philosophy in Indonesia; 2) Political Economy, with courses in the economic structure of precapitalist societies, capitalist economy, socialist and Communist economy, Dekon [Guided Democracy economic principles], the development of money and banking in Indonesia, cooperatives, and principles of statistics; 3 ) the International Labor Movement, with courses in general world history, bourgeois revolutions, the birth and development of the international workers' movement, theory of socialist revolution, and national liberation movements (Asia, Africa, and Latin America); 4) Problems of the Indonesian Revolution, with courses in Manipol and the Pancasila, general Indonesian history, cultural anthropology, Islamology, the Indonesian national liberation movement, general problems of the Indonesian Revolution, and Indonesian socialism; and 5) Language and Culture, with courses in Indonesian, Russian, and English languages and the history of Indonesian culture. Prospektus "Aliarcham" (Jakarta: Jajasan Akademi Ilmu Sosial "Aliarcham," 1964), pp. 6-7. The courses on cultural anthropology, Islamology, and Oriental philosophy, reflected both available teaching expertise and an effort at overcoming cadres' anti-Chinese and anti-Muslim prejudices (Sucipto and Sugiono, interview March 1965; and see Hutapea, "Proletariat Indonesia").

60 B. O. Hutapea, interview March 1965. 
selves with theoretical matters. The result of these differing levels and approaches was a good deal of confusion, leading in 1964 to a decision to establish three distinct diplomas for Aliarcham graduates: Sardjana Marxis (SM), for those whose party eminence entitled them to be considered expert after participating in some seminars and special projects, Sardjana Marxis Terbatas (SMT, basic Marxist scholar) for those who passed the full-time course, and Tjalon Sardjana Marxis (TSM, candidate Marxist scholar) for those who finished the extension program. 61

Some university students who belonged to the CGMI asked to transfer to Aliarcham academy, but the party was reluctant to accept them, for however much it made of the PKI's own educational system it valued a party supporter with a university degree more highly. ${ }^{62}$ Increasingly, too, the party put pressure on leftist university students to devote time to their books rather than to agitation; it wanted to show that Communist students were the best and the brightest, capable of socially responsible rule. ${ }^{63}$ The party leaders also wanted people with good claims to non-political expertise: capable technicians and managers who were motivated not just by the challenges of their field and individual material gain but by social commitment. ${ }^{64}$ Party leaders did their best to exude managerial competence, partly because that style attracted them, partly because it was the basis of the PKI's claim to power through the mastery of organization, and finally because it was a ground for acceptance as part of the ruling elite. These motives were intertwined but not entirely compatible: in particular the desire to win acceptance clashed with the claim to represent a superior approach to modernity than that proposed by the bourgeois West. In matters of higher education the PKI leaders tended to bow to the Establishment; hence their encouragement of leftist students to continue their bourgeois university education and their heavy soliciting of any non-Communist degree-holders who seemed at all sympathetic.

A major way in which the PKI could demonstrate to the nation its intellectual and administrative competence and at the same time improve the effectiveness of its mass organizational work was by conducting social research as a basis for practical policy recommendations, and in 1964 it was decided to make this a major focus of the Aliarcham academy effort. The high party school was therefore hived off administratively as the Akademi Politik Aliarcham. A research council (dewan ilmu) was formed, consisting of prominent party and sympathetic intellectuals, and important areas for research were identified. ${ }^{65}$ The principal projects sponsored in the council's first year involved team research into economic and agrarian questions; they were notable for framing their subjects in such a way that they were meaningful for governmental motives. In agriculture, the AISA asked not specifically about class relationships (contrary to the Aidit-led research discussed below) but about why one village was able to adapt new techniques and crops while another nearby and with the

${ }^{61}$ B. O. Hutapea, "Proletariat Indonesia"; in April 1964 fourteen people received SM degrees, seventeen SMT, and six TSM, indicating a considerable dropout rate.

${ }^{62}$ B. O. Hutapea, interview March 1965.

${ }^{63}$ This "bourgeois intellectual" and "peaceful-roader" attitude was much criticized by leftist exiles after the 1965 coup. See for example Supeno, speech of May 27, 1967 in Peking, Suluh Pemuda Indonesia 1, 13 (July 1, 1967): 4-5; Setia Murni, "Pensistimatisan Garis Revisionis dibidang Pendidikan," Suluh Pemuda Indonesia 3, 63 (March 11, 1968): 11-13.

${ }^{64}$ For a good example of the attitude see Harian Rakjat November 20, 1964, reporting a speech by Aidit of November 16.

65 The council, founded on March 8, 1964, consisted of Aidit (honorary chairman), Prof. Can Cu-som (chairman), B. O. Hutapea (vice-chairman), A. Sucipto, Dr. Suprapto S. H., Coo Tik Cun, F. Runturambi, dra. Carmel Budiarjo, Sugiono, dra. Ina Slamet, Prof. Can Cu-sim, Sunito Prof. Bakri Siregar, and Dr. Busonowiwoho Sumotirto. Harian Rakjat, March 10, 1964; Prospectus "Aliarcham," p. 5. 
same environment did not. What were the main factors in acceptance? What was the best way to introduce new methods in order to raise production? The economics project looked into the cost factors in basic food and clothing prices in major Indonesian cities: the number of stages and operations involved in the distribution system; the cost and problems of transport; and the sources and amount of wastage. ${ }^{66}$ These were questions of considerable importance, on which there was virtually no information at the time. They had patent relevance to any administrative attempt to redress Indonesia's economic problems; more importantly, they implied that these problems could be solved by knowledge and organization. Indonesians were not helplessly awaiting economic doom, they insisted: they could solve their country's problems by addressing them in a modern, scientific manner and then planning a rational response. And, not least, they hinted that the fountainhead of appropriate knowledge, even on technical matters, was the PKI.

Scientific councils and research projects busied the last year of the PKI's life. The Aliarcham academy established subsidiary dewan ilmu in other major Indonesian cities, which functioned partly to involve non-party intellectuals and partly to carry out research in subjects that local council members felt competent to promote. 67 The HSI academics' association set up a plethora of institutes, whose main occupation seems to have been the spawning of seminars and conferences. ${ }^{68}$ The BTI added to its Egom center in Cisarua the Jagus Scientific Institute for Agriculture and Seed Selection in Klaten. The women's organization Gerwani sponsored the Jajasan Pendidikan Taman Kanak2 to develop preschool programs. Only the labor movement, the PKI's stepchild in the later Guided Democracy period, seems to have lacked its scientific establishment.

This attention to winning respectability, together with the rapid expansion of the movement's bureaucratic apparatus and the opportunities offered by representative positions gained under Guided Democracy, raised a not inconsiderable danger of "bourgeoisification," of party members becoming content to take a slice from the existing system. To combat this, renewed stress was laid on organizational discipline, both by expanding the role of intraparty regulatory bodies, such as the verification and control commissions, and by renewing emphasis on teaching cadres how to organize. The Biro Pendidikan Sentral, in charge of supervising training within the party, was to see to it that cadres understood and exercised the principles of "compare, study, teach, and assist," which were the bases for self-criticism and the mutual enforcement of discipline. ${ }^{69}$ Party secretary

${ }^{66} \mathrm{Can} \mathrm{Cu}$-som, interview, Jakarta, February 1965 . The agricultural project involved 80 people, including rural sociologists and crop specialists, and lasted five months. The economics project ran for two months and involved 20 people; it was carried out in Jakarta, Medan, Makassar, and Semarang. Prof. Can stressed that the projects were not intended to provide finished research but were quick studies designed to produce guidelines for immediate action.

67 Interviews, Can Cu-som February 1965; A. Sucipto and Sugiono March 1965. Aliarcham branches existed in Bandung, Semarang, and Surabaya; in addition there were as yet unconstituted groups in Medan, Makassar, and Den Pasar. The major research project undertaken outside the Jakarta academy's auspices was on education. It addressed itself to the problem that available educational material was overwhelmingly child- and urban-centered, while what was needed for the Unra system was material that served adults and encouraged them to stay productively in the countryside rather than seeking to become pegawai in the towns (B. O. Hutapea, interview March 1965).

${ }^{68}$ These included institutes of Economic Science, of Political Science and Law, of Pedagogical and Psychological Sciences, and Health and Medical Science; it was planned to establish an Institute of History, Language and Culture; an Institute of Agricultural and Agrarian Science; and others. Harian Rakjat Minggu, March 14, 1965.

${ }^{69}$ In order to overcome tendencies to self-satisfaction and arrivisme, it was declared, cadres must 1) learn to work towards the goals of the party's development plan; 2) learn to perform work in many spheres; 3) learn to work in a rational, effective, and punctual manner; 4) learn to evaluate their own capacity and that of their environment 
Sudisman, reporting progress on this in mid-1965, noted that considerable strides had been made in improving cadres' discipline and understanding of the party's purposes. ${ }^{70} \mathrm{We}$ should not assume too much from this, for it was also a time of precipitate expansion in party and mass organization membership, and what was gained by improving the discipline of existing cadres was no doubt diluted by the inrush of untutored recruits. Nonetheless, a serious effort was being made to make the party a more vertebrate organism; and the emphasis on "socialist competition" between individual cadres and party units to fulfill development plans through "small but successful" campaigns no doubt affected the way in which Communist adherents conceived effective action.

Another way in which the PKI leaders sought to keep their link with the masses was by studying them. It had long been apparent to the party heads that they did not know enough about rural Indonesia to formulate an agrarian class strategy in which they could have confidence, and in 1959 the sixth party congress called for research into the nature of "feudal" exploitation in the villages. Investigation by party cadres into the nature of rural class relationships was subsequently carried out in Kediri, Surabaya, and Ngawi districts in East Java; Cilacap, Klaten, and Pekalongan in Central Java; and Cirebon and Bandung in West Java. However, such in-depth studies took too long and were too abstract to yield the kind of programmatic answers the party leadership wanted. Consequently, the PKI's seventh (1962) congress called for studies into the working relationships between landlords and peasants in order to be able to formulate appropriate ways to develop a movement to lower land rents; an investigation into working relations between farm laborers and landowners in order to formulate a campaign to raise wages; and specific studies of land use, cropping systems, and production costs in order to raise production and set realistic demands for reforming tenancy. ${ }^{71}$

Some of the results of these studies were incorporated into the guidelines that the party set down for cadres who engaged in the organizational effort that led up to the land reform campaign. ${ }^{72}$ The main burst of PKI research was undertaken, however, on the eve of the campaign in early 1964. It was not supervised by any of the existing PKI or BTI institutes but by Aidit himself, who over a six-week period led groups which studied conditions in West, Central, and East Java subdistricts (kecamatan). Thus in Central Java the party chairman oversaw the efforts of 56 researchers drawn from party cadres, mass organization activists, academics, and university students; and these in turn supervised the collection of material by 850 local rapporteurs in 29 kecamatan. ${ }^{73}$ As earlier research attempts had shown that the

so as to "reconcile soaring desires with limited capabilities," 5) learn to work diligently, steadily, and submit to periodic controls; 6) learn to organize properly. Harian Rakjat, July 3, 1965, from Sudisman's report to the fourth Central Committee plenum on the PKI four-year development plan. See also Sudisman, "Berkompetisi Sosialis untuk Mensukseskan Gerakan 4 Meningkat," Madju Terus 1, pp. 236-38; Basmi Penjakit Puasdiri, Jakarta: Depagitprop CC PKI, 1964).

70 Harian Rakjat, July 3, 1965. A campaign for ideological self-improvement among party cadres, the Gerakan Beladjar diluar Sekolah2 Partai (movement for study outside party schools), was also aimed at increasing cadre discipline. It concentrated on mastering the works of Aidit and other PKI leaders relevant to current party strategy. See Sudisman, Kerapian Organisasi (Jakarta: Pembaruan, 1964), pp. 5-15.

${ }^{71}$ Asmu, "Kembangkan Gerakan Enam Baik untuk Demokrasi, Persatuan dan Mobilisasi!" Madju Terus 1, pp. 203-204.

${ }^{72}$ See for example the lengthy article on village class divisions published in Harian Rakjat, January 18, 1964.

73Ibid., May 30, 1964, reporting a speech by Aidit in Semarang on May 29, 1964; see also ibid., June 5, 1964; and, for the experience of the West Java research effort, ibid., August 13, 1964, report by Ismail Bakri. The West Java research results were incorporated into D. N. Aidit, Kaum Tani Mengganjang Setan2 Desa (Jakarta: Pembaruan, 1964); intended publication of the others did not take place before the 1965 coup, but (presumably franker and 
usual practice of approaching village investigations through the village heads and other prominent locals meant either stonewalling or a strong bias in the information acquired, it was insisted that those visiting the villages must not work through them but must eat and sleep in the houses of ordinary peasants.

It was this campaign that originated the reports on village conditions which so impressed my Indonesian colleague twenty-five years ago. The people who authored them were rural activists, operating at the village and kecamatan level. In the specifics of their investigations they were guided by better-educated researchers, but, as the campaigns lasted for only six weeks and most non-locals spent only a few days in any one village, this probably had only superficial influence on the quality of their analysis. That no doubt stemmed from the longer-term influence of PKI education and agitation. They had learned to see their surroundings in terms of classes and interests, had come to believe these relationships could be altered, and that analysis and organization would bring understanding and improvement.

And what significance did this have for the future? A great many of the rural bearers of these ideas were massacred after the coup, while fear and disillusionment caused many others to reject all they had learned. A generation of military rule in which the peasants have been decreed a "floating mass" to be kept free from politics is not likely to preserve confidence in teachings which stressed mass mobilization. Moreover, the decay of communism and the rise of Islam as a focus of popular protest elsewhere in the world have brought into question some of the PKI's fundamental premises.

Whether and what role the Communist movement will have in a future Indonesia is for time to tell, but it would be a mistake to view the significance of the PKI's educational effort only in the light of the movement's political prospects. It must also be considered as part of the process of enlightenment which has been transforming Indonesia's civilizations starting with the "progressive regents" of late nineteenth-century Java and affecting ever broader segments of the population. The PKI, which in the postrevolutionary period was basically a movement of the petty bourgeoisie, ${ }^{74}$ transmitted these new ideas of modernity, rationality, and organization to the upper levels of the working class and the middle ranks of the peasantry. They responded positively because many people from these social groups were ready for alternatives to ways of thought which had become meaningless or had simply vanished from their lives. On the strength of the new thinking, activists from among them provided the organizational backbone for the broad following of the Indonesian poor, who looked above all to the PKI's promise of social justice.

The New Order has not removed the circumstances that attracted people to the postrevolutionary PKI. To the contrary, the rapid penetration of capitalist relationships and improved communications and education in the countryside have increased the speed of detraditionalization and the growth of materialist consciousness. Moreover, many of the fundamental concepts that Indonesian communism purveyed were also relevant to capitalist development: materialism, the centrality of economic relationships in society, modernity as the source of prosperity, analysis and rationality as the basis for decision making, good management as essential to success. One could have imagined quite a few of the PKI leaders

more detailed) reports of the research results were circulated internally (Aidit, interview, Jakarta, February 1965). Seventy kecamatan were investigated in East Java and twenty-four in West Java.

${ }^{74}$ Aidit, quoted in Harian Rakjat, February 7, 1965; and see the survey of party membership made public at the PKI's 1962 congress: P. Pardede, “Laporan Komisi Mandat kepada Kongres Nasional ke-VII (Luarbiasa) PKI," Madju Terus 1, p. 168. 
as business managers under another dispensation, and indeed the party's educational work may have done its bit to increase Indonesians' entrepreneurial potential. In one sense, therefore, the PKI and New Order ideologies are different channels of the same stream, whose source is the great myth of modernity. At the same time, the values of popular participation and social justice which the PKI urged are suppressed but certainly not forgotten; they resonate in the urgings-now faint, but stirring-for a new recognition of the Indonesian common man. 
